\title{
A Theory of Literary Realism
}

\author{
Ali Taghizadeh \\ English Department, Razi University, Kermanshah, Iran
}

\begin{abstract}
The European Medieval romance was far from realistic. However, the modern literary realism both in England and America has been multi-faceted. An English face of it is often the manifestation of man in search of salvation via the application of his mental capacity in a chaotic world of tension and progress. In his remote island, the hero of Daniel Defoe is concerned mainly with the development of his kingdom and the application of his sovereignty over the natives. But an American form of literary realism is that however the romance is not divided in it from the novel, but it shows the present as sharply separated from the past. The realism of Howells is the realism of here and now, that of Mark Twain is a criticism of the present social situation, and the realism of James is often concerned with the psychological development of his key characters.
\end{abstract}

Index Terms — romance, novel, representation, English realism, American realism

\section{INTRODUCTION: ROMANCE VERSUS NOVEL}

Realism is often multi-faceted. Literary scholars often find it in relation with the rise of the novel, and thus rightly claim that it is narrative. Another facet of realism is the relation between literature and reality, between what the word says and what the life is. This dimension is usually dealt with under "representation" which is psychological, cognitive, as well as anthropological.

It can be argued that the novel is the literature of the bourgeoisie, and the romance, which is a major precursor of the English novel, was the literature of feudalism. In the present study, a question is what type of literature the romance was, and how it should be compared with the novel. Romance, or chivalric romance, takes elements from legends, fairy tales, and history. It is a form of heroic prose and verse story that was popular in the aristocratic circles of the medieval and early modern Europe. The romances typically narrated the knightly adventures of a valiant hero who often fell in love with a beautiful lady from a noble family with ancient pedigree. To take the hand of his beloved and gain the honor of knighthood, such a warrior-lover had to prove that he could defend the values of chivalry and heroism, that he was faithful to the tradition of "courtly love," and that he could defeat all the enemies of his society. Therefore, he had to quest for a brave errand of heroism that included a series of dangerous adventures. The romance was highly elevated in form and content, and was therefore a suitable type of literature for the representation of the manners of the gentry: kings, soldiers, lovers, etc.

However, in its rise and role, the English realistic novel was in sharp opposition to the romance. If the romancer felt free from the moral reality, and if he would therefore compose a story that was quite subjective and had nothing to do with the real human society, the realist novelist would feel a heavy load on his shoulder to provide an objective rendition of the meaning of humanity. From the outset, the English realistic novel has objectively concerned itself with the daily life experiences of the common man and woman coming from the lower and/or middle classes of the early modern society. In addition, the fact that the novel was in prose as the language of the practical people, made it possible for its writer to free himself from the necessities of the elevated language of the romance. So, the simple flow of the prose language into the smallest nooks and corners of the human consciousness allowed the novelists to represent the minutest details of life experiences of the average man.

The appearance of female society, the increase of wealth, the mandatory education, and the development of journalism had also significant roles in the rise and development of the English novel as a product of realism. The higher class women, who had a lot of free time to pass at home, started to be regular consumers of the novel, because for passing their leisure time conveniently, they needed something to read. In such a situation, compulsory education led to a rapid increase in the number of men and women who could read (prose) fiction. And the development of journalism, which was itself a result of compulsory education, was influential not only in the technical promotion of story-telling, but also in making the readers more interested in the novel, because the publication of the life stories of novelistic characters in sequential issues of the magazines made it possible for the readers to follow the stories of such characters. These factors, in addition to the invention of the printing industry, the development of public health, the increase of leisure time, and the progress of public transportation changed the novel from a minimally- or privatelysupported medium of culture and education to a publically-supported medium. And this, in turn, helped it to become more deeply integrated to the development of realism in Western cultures.

Moreover, if the representation of life in romance is more subjective, in the novel it is more objective. This means that doing his job, the romancer used to feel greater freedom from the social standards, whereas the novelist feels committed to represent the reality of the human experience. For Richard Chase, 
The main difference between the novel and the romance is the way in which they view reality. The novel renders reality closely and in comprehensive detail. It takes a group of people and sets them going about the business of life. We come to see these people in their real complexity of temperament and motive. ... Character is more important than action and plot, ... The events that occur will usually be plausible, given the circumstances, ... By contrast the romance, following distantly the medieval example, feels free to render reality in less volume and detail. It tends to prefer action to character, and action will be freer in a romance than in a novel, encouraging as it were, less resistance from reality (1957, p. 12).

Another feature of the realistic novel is the absence from it of the great people of romance and their heroic actions. Novel is not suitable for representing the manners of aristocracy like heroism and courtly love. It is also not interested in dramatizing the superhuman characters of romance and their incredible and fantastic incidents. Instead, it tends to dramatize the life experiences of average men and women as they are involved with the real ups and downs of daily life. Characters in a novel typically represent the members of lower and middle classes. The representation of such people in the novel implies, as Sir Walter Scott says, that it speaks "the dialect, the language" that people "know-the language of unaffected people everywhere” (qtd. in Miller, 1967, p. 265).

\section{DISCUSSION}

\section{A. Realism in English Novel}

\section{In Daniel Defoe}

The language of the novel is perhaps as diversified as the real speakers are; and it is prone both to lexical and grammatical deviations from the standard dialect. This means that the language of a novel can be as fully slangy, conversational, and colloquial as the man of business, who has something on the tip of his language to express, can speak with no attention to the form and lexicon of his expression. The diversity of the people represented in the realistic novel guarantees that it can be widely inclusive in plot, theme, and characters, for in their humor, motivations, inclinations, etc. the people of the novel can be as different from one another as real people are different. Thus, depending on the people involved in the realistic story, "everyday life" means different things and includes a whole range of concerns: love, hate, death, pride, greed, poverty, failure, success, struggle, sexuality, etc. And the characters are shown in their real attempts to develop their lives, or even to survive, in a (transient and paradoxical) society that is sometimes harsh and nonhuman.

In this way, if in realism the representation of "everyday life" is elemental, it can be argued that in different novels and for different characters it means different things. For example, for a highly ambitious and fully aspired young man like Robinson Crusoe in a novel by Daniel Defoe, it meant how to apply his power and wisdom to create life out of almost nothing on his remote island and how to survive there for about 29 years: firstly to get saved from the violent sea storms, then to primarily settle there on his island and to tame it, then again to manufacture the things he most needs, to open a plantation, to grow goats and sheep, to kill the wild animals, to teach the Bible to his man Friday, to surrender the native settlers, to exploit them to his own advantage, etc. the sum total of which meant to restore his sovereignty in his privately-established state.

The purpose of the English novel is to convey the impression of fidelity to human experience. Therefore, another mark of distinction of the novel is the newness of its subject matter. This adds to the role of the author also, because representing the variety of the modern life goes counter to the repetition of the previous plots, and it needs the creativity of the author. Such valuation of the individual means that learning is a reliable source of inspiration which can take the place of the sources of collective tradition whether they be scriptures, legends, or histories.

Thus, it is logical that the novel is more formless than the romance, tragedy, or epic. It can perhaps be as formless as the individual experience can be limitless in type and volume. For example, the story of Robinson Crusoe is free from tradition, and flows as spontaneously as Defoe plausibly imagines the daily lives of his characters. This is to mean that if a Medieval text, Roman de la Rose for example, was composed on the basis of the French tradition of courtly love, the plot of Defoe's novel develops as the hero narrates the incidents of his own life and history when he sets sail from his hometown in York, England, for an unknown destination in search of a new life. This is a wholly invented plot that originates not from tradition, legend, mythology, or history, but from the personal experiences of the author, from a series of fictive adventures when the hero ventures to go on a tumultuous journey to establish a state in the foreign lands.

The actors in an English novel are also different from those in past literatures. The human types of epic and romance are replaced in the novel by particular people who arrange their lives in particular circumstances. Therefore, it is not the accepted universals of life, but the experiences of certain men and women, that define in the novel the reality of the consciousness. In this way, in the rise of the novel the concept of "reality" changed also; and the material of realism emerged from the immediate sense impressions of the individual man. However, although Robinson Crusoe has a lot of knowledge and experience, the base of truth is neither his knowledge of an accepted tradition, nor the outcome of an individual sense impression in the particular sense. Thus, the individual man of the novel has an intellectual responsibility for the recognition of reality: he has to give shape to the unshapely flood of sense impressions by filtering them through his consciousness.

But if this new form of literature should be widely appreciated, the critical tradition should also change, for in the culture of the readership the new values of originality and particularity should take the place of the classical values of 
repetition and universality. However, the dissatisfaction and departure implicit in originality, along with the power of the novel to depict the state of thought and feeling of the past generations, make the novel appealing enough to the newly emerging readership, for they could read the life story of particular men and women who were like themselves.

Additionally, the new critical atmosphere in the emergence of the novel was to give birth to new methods and standards for characterization and for the presentation of environment. It is essential that the reader of the realistic fiction collaborates with it, for in the act of composition, and by taking distance from the characters through observation, the author registers them on his/her consciousness as real and independent human beings. Thus, for preserving the "illusion of reality" in the story, the reader should infuse his own experiences with those of the characters. It can be suggested that the English realistic novel is a drama of intellectualization, for it depicts not only the state of intellect of the past generations, but also that of the readers. In the space of the novel, we not only frame our feeling and structure our intelligibility, but also discover how we are integrated to our society. Winfried Fluck perhaps means this when he describes realism as an optimistic project in America. In "American Culture and Modernity: A Twice-Told Tale" he argues that realism is a cultural project for the individual to communicate with himself and about himself.

\section{In Henry James}

But the fiction of Henry James, whom Cathy Kurtzman Lawrence calls "the main proponent of American realism" (2004, p. 287), wants to remove the divisions between past and present, and to bring the spirit of history to the modern times. Roger B. Salomon discusses James's concern with the past as in the following.

Though he had moments of being swept away with nostalgia, James' most profound vision is not of escape to an ideal past of dreams and fantasy but of the preservation of a real past as a dimension of the living and active present. For James the present could literally incorporate the past: make it, that is, one in body. Without a past, an individual or a society had no identity — no "tone" to use James's favorite word (1964, p. 542).

Thus, we can and should revitalize the past as a source of meaning for our present existence. Such inclusion of history in the present explains the Jamesian verdict that human relations are "the essence of history" (qtd. in Solomon, p. 542). This makes the Jamesian concept of human experience increasingly complex, while a question is how his modern reader to conceive of this sense of continuity of experience in a time of rapid changes. Salomon says James's solution was "a testimonial to the value of memory and imagination" (542).

The fiction of James allows the reader to intensify his experiences through the use of all his imaginative faculties for turning the past of his characters into imaginative simulations. However, James's realism means also the way he conceives of characters and the tasks he ascribes to them. He considers them as real - living - people who not only propel the narrative but also really perform the action of it. "You" and "I" are absolutely presupposed by one another. Without "you" there is no "I" and without "I" no "you". In the fiction of James, the narrator and character (the teller and listener or reader) are as real as "you" and "I" who relate our narratives. However, like us, the people of James are limited to what they can observe or know.

No mode of knowledge is central, and no hierarchical relation is available between the levels of knowledge. Instead, some classical ontologies want to be represented and play roles. Instead of arborescent frames of intelligibility, structures of relations are often nodal, interconnectiveness is a key function, and reference is often to the external, to the beyond, to otherness. In a cultural environment, this rhizomatic structure is made of horizontal and trans-species interconnections that want to form a multiplicity of simultaneous realities. This in-between structure can found itself nowhere, for it is always on the move. It is not only always in transmutation but is also an agent of metamorphosis. Like James's house of fiction that has several outlooks for the exchange of negotiations, this structure has perhaps numerous slots through which new epistemes can be inserted.

In What Maisie Knew James provides us with the occasion to understand how the consciousness of an infant girl develops to maturity and moral sense in a world of promiscuity, selfishness and enmity. For F. O. Matthiessen, the novel is "typical of the later writer's refinement of skill and sophistication" (1941, p. 279). He says James

would set himself the complicated problem of having both parents divorced and married again, of making the child the innocent meeting ground for a liaison between the step-parents, and of confining his report on the situation entirely to what could be glimpsed through the child's inscrutable eyes (1941, p. 279).

For doing this, James chooses the consciousness of Maisie Farange, because, as he notes in the preface of the novel, "the sensibility of the female young is indubitably, for early youth, the greater, and my plan would call, on the part of my protagonist, for "no end' of sensibility" (qtd. in Veeder and Griffin, 1986, pp. 318-319). Maisie is introduced to a chaotic familial and social environment where the good and bad of life stand in sharp contrast. Such oppositional life frightens her faculties. On the one hand, we see the development of things in her limited consciousness as central intelligence. On the other hand, and not to exceed the law of probability, the author carefully controls the expansion of her understanding. The result is that although from the outset she appears promising, but she never understands much more than what her age allows her. The reader sees things in and through her mind, but he is allowed to understand much more than her.

However, for a character in a novel by Henry James, for Kate Croy in The Wings of the Dove for example, realism meant the application of a long sequence of clever strategies to win the love of a man via which also to get rid of her own extreme poverty. To achieve these things, Kate has to use her wit as another meaning of realism in her story. Firstly she has to get rid of her wretched and reprobate father who is making great problems for her. After that, she has 
to compromise with her sister and aunt to get the benefit of their advice and support. Also, she has to do her best to win Densher's love only through which it will be possible for her to lawfully possess the fortune of Milly Theale after her death.

\section{B. Realism in American Novel}

\section{Emergence of Realism in America}

European realism does not apply neatly in America, because however it was a neoclassical movement, American realism was perhaps far from neoclassical. This is because contrary to the European realism, which originated mainly from the classical Greek and Roman heritage, American realism borrowed almost nothing from it. Instead of reflecting back to the antiquities, American realism has been concerned with the reality of the American life in the $19^{\text {th }}$ and early $20^{\text {th }}$ centuries. One may accept that Alexis-Charles Tocqueville (1805-1859) had already observed individualism in America of the 1830 s, but in the $19^{\text {th }}$ century one would believe in the existence of no widely accepted definition of American realism, because in those times it was still quite new.

In the $19^{\text {th }}$ century, there was still no series of concepts available for American realism, and no manifestoes, literary models, or schools of thought that could organize and differentiate the upcoming original works and scholarships. Thus, it can be suggested that American realism has grown by trial and error, by accumulation rather than by design; and for explaining its influence on the American fiction, it would be advisable to consider different stages of its development. In this way, when we discuss American realism, we should deal with a course of development rather than a collection of concepts and theories.

The $19^{\text {th }}$-Century American fiction has gone in divergent ways. But its more significant writers have many things in common. In the $19^{\text {th }}$-century America, romance was not a genre of the past times, and the realistic story was getting established by making its social repertoire, defining its subject-matter, and addressing a middle-class consumer. There in America the romancer has had occasion to re-enliven the ideals of the feudal hierarchical society through portraying the fantastic and superhuman characters of heroes, warriors, kings, and courtly lovers in a series of fabulous incidents.

\section{Bi-polarity of American Fiction}

A central question in the present paper is the difference in the connection between romance and novel in England and America. The English novel is a later and more developed stage of romance, so that with the publication of Don Quixote, in which Cervantes had satirized the chivalric romance of the medieval times, almost no other romance appeared on the stage of the European literature. However, in America the romance is not separate from the novel. The contrast which Richard Chase makes between English and American romance is angled toward this difference. Chase affirms that,

Although most of the great American novels are romances, most of the great English novels are not -- the fact, in other words, that the tradition of romance is major in the history of American novel but minor in the history of the English novel (1957, p. xii).

Chase also argues that the novel in America is a development of that in England. However, he approves that the English imagination has followed "a middle way" through cultural contradictions to produce a fiction of unities and harmonies, while the American imagination has captured the cultural opposites and disharmonies to produce a fiction of extremes and contradictions. It is perhaps for the illustration of such contradictions in the American humor that the novel in America has involved itself with romantic elements, the elements which it has perhaps not attempted to reconcile. Such involvement with polarities in the American novel has excited Nathaniel Hawthorne to admit in the preface of The House of the Seven Gables (1967) that although the realist novelist feels committed both to the probable and the possible, the romancer feels freer from them. This is to mean that while the truth-seeking imagination of the novelist impels him to show fidelity to the minutest of man's experience, the opinion of the romancer is more latitudinal, and his truth is the result of his own choosing or creation to which he shows an indirect fidelity through a range of language resources like myth and symbolism.

Before the Civil War in America, the romancers attempted to break away from the romantic tradition and compose stories in the style of Dickens and Thackeray for example, that had dominated the American market. However, Perry Miller argues that a "cultural lag" kept them back from doing this job. Comparing the English and American fiction from this perspective, Miller says

In England we can see how the rapid urbanization forced upon the generation of Dickens and Thackeray themes arising from the turmoil of London, the black smoke of Manchester and Birmingham, the social competition of Barchester and Grosvenor Square. But the creative imagination of this country had taken shape amid the single reality of vast, unsettled traces of wilderness. Crowded and noisy as New York seemed to country visitors in 1850, it was still not sufficiently a pile of "civilization" to make imperative a writer's forsaking the wilderness for the urban scene. The dream of Arcadia died hard. A civil War was required to shatter it (1967, p. 258).

If the lack of "civilization" was a major reason for the jointly presence of romance and realism in American fiction, "local colour" fiction was also influential in their embedding. This kind of story implies man's nostalgia to unify with his regional environment, and shows how he manages his relations with (external) nature, how he comes to terms and feels at home with it (when it is fierce and hostile). Of the external landscape, the writer of a local colour story creates all the paraphernalia of an imaginary situation. Therefore, if it can be suggested that the reader internalizes the values of 
such a created fictitious world, it can also be proposed that the local colour fiction has been effective in preserving the romance in American fiction.

\section{In William Dean Howells}

However, the realistic novel was still beginning to find its way to the reading public in America by opening up new areas of subject matter that belonged to the lower and middle class people. The fictions of Mark Twain and William Dean Howells, who were perhaps the most well-read story writers in that mode, provoked often a humorous social criticism of the $19^{\text {th }}$-century American life. And Henry James dealt with the realism of the human consciousness in a most subtle and eccentric way.

Therefore, in finding solid footholds and formulating itself, American realism should have had hard times. After the civil-war, the writers with their critics and audiences started to feel interested in an exclusively American culture which would show the ways of life and thought that were native entities rather than imported products. If this did not necessarily mean that the American new generations had firstly to reject all cultural folds imported by their forefathers from Europe, at least it meant that for creating a specifically American civilization, they had to address American thought and feeling. However, the new empirical vision in the 1860s that was the outcome of the triumph of science and patriotism, and that would mingle with a heightened national consciousness, is another ground for the emergence of the American realism.

In Literary Movements for Students we read William Dean Howells "earned distinction as a highly influential literary critic, championing the realist writing of American authors Henry James, Mark Twain, and Stephen Crane as well as European authors Ivan Turgenev, Henrik Ibsen, Leo Tolstoy, and Emile Zola" (Galens, 2002, p. 248). Howells published his critical ideas mainly in the magazine Atlantic Monthly to which he was an editor for about 15 years. The journal gave him occasion to scrutinize the new American social scene for the formation of a typically realist fiction. Bernard R. Bowron JR. quotes from Howells that in the America of the late nineteenth century the new life was a "commonplace prosperity" (1951, p. 268). This shows that another meaning of the $19^{\text {th }}$-century American realism was a sharp break between the past and the present. Rejecting the past as unreal and irrelevant to the present would imply that the real is limited to the tangible, to the palpable, to whatever man can learn only through his sense impressions. In this way, the here-and-now became not only the object of dramatization but also the great source which inspired the realistic story-teller through his own intelligence. The author would necessarily zoom in on the foreground where there were the smiling aspects of life, for in the background are the streaks of the past life that is full of hazards and wanderings.

In the European culture, the past was not regarded dead or insignificant, but one period was embedded within another so that the past was contained in the present. This means that a cultural continuum was the novice of realistic literature which would hold up a mirror for reflecting the history of civilization. However, although in America there was a meaningful involvement with the past, but fiction would re-enliven the spirit of the past in the context of the present which the modern reader could recognize only with the sensibilities of his own time. This policy of historical superimposition had a certain reason: that, as Roger Salomon says, "the picturesque tradition was unable to deal with the present, and so realism made a religion of newness and contemporaneity" (1964, p. 537).

Wayne C. Booth affirms that "To ... Howells, the obvious thought occurred that life is 'really' often quite pleasant" (1961, p. 55). When the former considers the latter a social realist, the present reader believes he is right, because American life in the time of Howells was subject to progressive evolutions, and he saw the radical developments in literature in good harmony with such social changes. He recognized literature as a product of life, and as lawful as its other manifestations. His other postulate about literature is that like life, literature changes for better. As life moves from primitive to more civilized conditions, literature is also mutable; and it progresses internally as well as externally. Internally, it develops in form and technique, while externally it progresses in subject matter; and it devotes itself to truthful accounts of the human life.

Donald Pizer argues that literature for Howells was to embody a truthful description of contemporary life, but that he advocated a scientific role for literary criticism. However, he notes that "Howells's limitation of the function of criticism denied to it, above all, the right of judgment" (1984, p. 79), because he believed that criticism was marred by our taste, prejudice, and wit. Criticism was not to direct or control the progress of fiction, but was to describe and analyze fiction on the basis of a realization of the law of progress as it operated in society. In other words, criticism was supposed to want to determine to what measure fiction was in harmony with the expected developments in society. This is perhaps because Howells thought contemporary criticism was a failure, for it was retarded and backward, and could not recognize the intrinsic relationship between life and literature.

In Howells's view, the literature of the past is anachronistic; while modern literature is more truth-oriented and lifelike. Howells refuted two charges against American fiction. One was the idea of sex. He admitted that American novel dealt with sex less openly than both the eighteenth-century English fiction and the contemporary French fiction. But he also claimed that by subordinating sex, American fiction represented its true position more accurately. The second charge was that American literature was too narrow. But Howells saw this rather as an advantage, since it indicated a truthful representation of the conditions of American life. The American novel is, for Howells, a thorough account of life, and its depth is vertical rather than lateral. Such depth is more desirable than a horizontal expansion in a civilization like America, where the differences are not of classes, but of types. 
He also deals with the relation between literature and democracy. In democracy man feels sincerity, and the writer searches for measures of improvement and for responding to the spirit of brotherhood that is implicit in it. American democracy has paved the road for its expansion and variety. In the wide and various environment of it, literature has been encouraged to study and appreciate the common man, and to portray the finer and higher ties which unite rather than sever humanity.

Howells neither idealizes reality nor does he always stick to the pleasing dimensions of life. As an opponent of the ideal and a decisive advocate of the real, he dramatizes the ugly scenarios of life. However, an aspect of amelioration is not to represent life as lacking violence, but to control and undercut violence in fiction. In the "Editor's Study" column at the Atlantic Monthly, and later on at Harper's, he has formulated and publicized his theories of realism in literature, and has clearly defended the real while opposing the ideal. From the eye of Howells, the standard of reality is the taste of the common man, what the average man admires and selects. Reality is admirable because of its simplicity, naturalness, and honesty. The real is true to life and sincere with man, and man can stand in direct relations with it. The genuineness of the real and its organic wholeness render it faithful to life. The real delivers itself from the evils of the romantic and the heroic and the impassioned and the sentimental; from the self-devoted and the adventurous; from the trite, and the obsolete. The real is always new, fresh, absorbing, and life-giving.

Howells takes no use of what inspired moments may grant him. His method is careful observation of the minutest details of life with force. His native gifts constantly develop, and he continuously grasps the facts more strongly. A major theme of his work is the problems of character and social life. Thoughtful readers of his work realize an inspiration in the quiet but resolute progress of his art and gift which is the result not only of success but doubtlessly also of a high and disinterested ideal. The work of Howells is the product of patience and effort rather than original power. The virtues and effects of realism are clearly brought out in his work: its clearness of sight, its fixed adherence to fact, its reliance upon honest work; and, on the other hand, its hardness, its lack of vitality, its paralysis of the finer feelings and higher aspirations, its fundamental defect on the side of imagination. His fiction is crowded with characters of realism: people with whom one avoids to come into contact in real life, people without native sweetness or strength, people without any acquired culture or accomplishment. He portrays characters without force, beauty, aspiration, or any of the elements which touch and teach men. And he delivers grave portraitures of frivolous, superficial, and often vulgar conceptions of life. In The Rise of Silas Lapham, Howells' method of realism is external and superficial. He endeavors to enter into the recesses of character and to learn its secret, not by insight, the method of imagination, but by observation, the method of science.

\section{In Mark Twain}

In Adventures of Huckleberry Finn, Mark Twain takes use of the advantages of, among other things, the vernacular, point of view, setting, satire, irony, and innocence portraiture. He produces the tale of a young boy whose disrespect to overwhelming conventions helps the reader to envision a world where there is not only no inequality between humans but also no ignorance, greed, and cruelty. However, this story does not move from plot to character, for the author creates a picaresque story that is based on a series of extraordinary incidents undertaken mainly by Huck Finn whom the story exposes to various social worlds.

The fact that the viewpoint of this young boy is the central perspective from which the reader has to look implies a decrease in the role of any kind of authorial omniscience. The reader has an occasion to look at the thoughts of Huck who writes his story in the first-person point of view. As well as a successful search for freedom, reading this novel is a process of interpreting the consciousness of a main character who has started to see the world in his own way. As Huck and Jim voyage down the Mississippi river, the reader can see them in moral conflict with the received values of their society.

The reader of this Mark Twain's story can also realize the dramatization of their consciousness through the medium of talk. Interpreting their outlooks is perhaps the most important job of Mark Twain's reader. Huck and Jim travel southward as a quest for rejecting slavery, patriarchal authority, and the restricting catechisms by which the author thinks their genuine humanity is suppressed. When Huck encounters Jim in the wilderness along the river, at first he opposes the latter's trying to escape slavery. After they talk, Huck changes his mind about life, which illustrates the modification of an individual mind in a process of talk. In fact he encounters with another different human being and his life-situation.

Also, presenting the life of innocence in human society, Mark Twain's realism is convenient to the representation of what is called "the mask of the naivete" (Kolb, 1969, p. 73). Integral to the mission of the main character is his escape from the overwhelming conventions of society and his attachment to the natural rhythms of life. The main character is an unsophisticated fourteen-year-old boy who is quite innocent and has no experience about the decadent life of the adults who believe that slavery is just. His "freedom ride" is for the eradication of whatever segregates man from man and puts one man in a socially privileged position over another. Huck's naive unawareness is the author's effective reason to avoid evaluating what the characters do, interpreting the story, and motivating the reader to rewrite it in the process of reading. In this way, to represent the inhumanity of segregation, the novel shows that the struggle against slavery is not an aspect of convention but is quite natural to man.

In the realism of this novel, irony has more than one level. Although the author does not use primarily verbal irony, he makes effective use of the advantages of structural and situational irony to represent man as a mixture of good and 
bad. At the end of the novel, when we realize that although Jim is black in skin, he is, as Kolb puts it, as "white inside" (76) as the white people, we understand why Mark Twain has accepted to look at man through the innocent eyes of a young boy whose symbolic long voyage on the river leads us to a utopia of peace, brotherhood, and social reconstruction. All religions of the Mississippi Valley (the religion of the Widow Douglas, the catechism of Miss Watson, the preaching of Silas Phelps) support slavery. But it is ironical that Huck cares for none of them, and that his childish carelessness for them should cancel their function because they condemn Jim to slavery.

If Huckleberry Finn rejects the pleasures of society to practice another kind of life where the logic of nature teaches us how to live more humanly, Maisie Farange struggles to develop her immature perspective about the world while she actively interacts with family and social life. Huck tells us his own story in the first person point of view. This is while although Howells believed in the historical mutation of American literature for the better, but he denied the right of judgment for literary criticism. Both Maisie and Huck succeed to leave their decadent societies behind and find a solution for themselves: the first in the form of a moral idealism which leads her to precocious knowledge and insight, the second by undertaking a chain of picaresque adventures that put him at the threshold of conversion since they are in sharp opposition with the norms and ideas of his community.

Although Huck is not, from the beginning, quite conscious about the conflicts of the society, he is, perhaps unconsciously, aware that for the salvation of this society certain of its personal and collective codes should be canceled out. But Maisie's development is more unconscious. The more actively she interacts with adolescent people, the more positive of their corruptions she comes to be, and her moral sense gets deeper. If Mark Twain's story shows the external fact of American mass life in need to alert itself to the necessity of love and brotherhood, Maisie deals with the realism of a developing human consciousness as it struggles not to get corrupted by the widespread moral decadence shown in the environment.

If Howells shows the present as inadequate to renovate the soul of the heroic past, Salomon admits that "Twain eventually gave up trying, and Henry James, by and large, never made the attempt" (1964, p. 539) to do so. The realist Mark Twain perhaps does not even remain split between past and present, but mainly zooms in on the latter. His realism shows no feeling of nostalgia about a lost past full of heroic and romantic values, and his nostalgic characters never grow to maturity. His characters are denied the possibility to unite imagination and rational experience to develop a socially integrated personality. However, Salomon sees him as nostalgic also:

We are face to face, of course, with Twain's nostalgia, his 'homesickness' for the home that had been destroyed, his sense of wondering in exile from a 'lost country'. The sentiment is common to the century and is the product of the same forces that were to produce realism: change, disorientation, the 'hateful' sense, as James put it of 'personal antiquity', of being able to trace in one's lifetime where 'an age has come out'. ... The crucial fact to remember about Twain is that he was intellectually committed to realism and emotionally committed to a nostalgic sense of the past (1964, p. 540).

The fiction of Mark Twain opens a way for the reader to comprehend a meaningful relationship between past and present by representing the past as reduced from the heroic to the sordid. The ambitious look of Americans to the future, that focused on their rapid scientific and technological developments, caused its realism to ignore the romantic heroisms of its past, for the American republic was fascinated mainly with innovations in science and technology. It is this diversion of realism in America away from the moral (past) that Salomon calls "the aesthetic of disinheritance" (1964, p. 533).

\section{CONCLUSION}

Literary realism is multi-faceted. The English mode of it is itself of more than one genre however it also differs from the American mode. In addition to its cultural varieties, the strategies of each mode of literary realism are different as well as the problems and issues of each variety. The realism of the European romance in the Medieval Times was the realism of the gentry which was itself in the minority. This kind of realism was often limited to the manifestations of courtly love, kingly conducts, and knightly manners. It was considerably romantic and was therefore only marginally considered.

But in the $17^{\text {th }}$ century the Spanish writer of Don Quixote satirized the conventions of the Medieval romance for its excluding focus on the life of the gentry and overlooking the life of the middle and lower classes. As an aftermath of this history-making epoch, it was before the last years of the $18^{\text {th }}$ century that the (realistic) novel appeared on the horizon of the English fictitious literature. However, although The Adventures of Robinson Crusoe was perhaps the first fiction of this type, it was followed by a long series of novels in this mode. In the course of several decades, the field of realistic fiction became enlarged and diversified enough to cover perhaps all the nooks and corners of the European life which was in a rapid process of transition. Around the Neoclassical Period and the Age of Enlightenment, all those church divisions and religious controversies, political debates and parliamentary fractions, philosophical arguments and scientific innovations, as well as economical and monetary improvements changed the English social life into a boiling pot which included even opposite items: power, colonialism, wealth, poverty, love, family, homelessness, failure, fraud, honesty, lovelessness, non-belonging etc. Therefore, the realism of everyday life, which the novel was taking to represent, was as diversified as the European man himself. 
In this regard, the present paper has attempted to argue that the English literary realism in typically different from that in America. In the English novel, the past is not divided from the present, but is embedded in it. That is, the illustration of history in it is in a way that it often revitalizes itself in the present so that the reader realizes a cultural continuum or a plotline of historical consciousness. However, in the American novel, perhaps due to the lack of a long national and cultural history, there is often a feeling of regret and nostalgia about a past that is lost and out of reach. This unreachable history is dramatized perhaps better in the works of William Faulkner and F. Scott Fitzgerald. And although W. D. Howells believed in the historical mutation of American literature for the better, but he denied the right of judgment for literary criticism. In addition, Howells found the development of literature directly connected to democracy, and claimed that in the expansion of democracy literature gets expanded also.

On the other hand, the author of Adventures of Huckleberry Finn analyzes the American present. Instead of zooming on a lost and unreachable past, Mark Twain looks upon the present America to examine and reject the social misbehaviors like racism, slavery, and class segregation. And the realism of the later Henry James is often concerned with the evolution of the mind in narrative language. In a majority of his works, he creates a mode of realism which is psychological, and as psychological, deals also with the production of experience in a process of interpretive analysis in reading. In The Ambassadors James sends a highly talented relegate of the American culture like Lambert Strether to trace the development of his consciousness as he copes with the Parisian culture. However, in What Maisie Knew he provides us with an occasion to witness the progress of an infant girl who is surrounded by promiscuity, enmity, and selfishness.

\section{REFERENCES}

[1] Booth, Wayne C. (1961). The Rhetoric of Fiction. Chicago: The University of Chicago Press.

[2] Bowron, Bernard R. (1951). "Realism in America." In Comparative Literature, Vol. 3, No. 3: 268-285.

[3] Chase, Richard. (1957). The American Novel and Its Tradition. NY: Doubleday \& Company, inc.

[4] Fluck, Winfried. (2003). "American Culture and Modernity: A Twice-Told Tale. "in REAL: The Yearbook of Research in English and American Literature, vol. 19. 65-80.

[5] Galens, David. (ed.). (2002). Literary Movements for Students: Presenting Analysis, Context, and Criticism on Literary Movements. Detroit: Thompson.

[6] Lawrence, Kathy Kurtzman. (2004). "Margaret Fuller's Aesthetic Transcendentalism and Its Legacy." in The America Renaissance. Edited and with an Introduction by Harold Bloom. NY: Chelsea House Publishers. 273-296.

[7] Kolb, Harold H. (1969). The Illusion of Life: American Realism as a Literary Form. Charlottesville: The UP. Of Virginia.

[8] Matthiessen, F. O. (1941). American Renaissance: Art and Expression in the Age of Emerson and Whitman. New York: Oxford UP.

[9] Miller, Perry. (1967). "The Romance and the Novel." in Nature's Nation. Massachusetts: The Belknap Press (of Harvard UP.): 241-278.

[10] Pizer, Donald. (1984). Realism and Naturalism in Nineteenth-Century American Literature (revised edition). Carbondale. State Illinois UP.

[11] Salomon, Roger B. (1964). "Realism as Disinheritance: Twain, Howells, and James." in American Quarterly, vol. 16: 531-544.

[12] Veeder, William and Susan M. Griffin (Eds.) (1968). The Art of Criticism: Henry James on the Theory and the Practice of Fiction. Chicago: U of Chicago P.

Ali Taghizadeh is an assistant professor at the English Department of Razi University of Kermanshah, Iran, where he has taught English Language and Literature at graduate and undergraduate levels for about 16 years. He has got a B. A. in English from Shiraz University and an M. A. in English from Tehran University. The title of his M. A. thesis is "The Archetypal Theme of Expiation in Six Major Novels of Thomas Hardy and William Faulkner: A Comparative Analysis." He has also got a Ph. D. in "American Studies" from John F. Kennedy Institute for North American Studies of Free University of Berlin. The title of his doctoral dissertation is "Structuralism and Its Aftermath in the Fiction of Henry James." "Novel", "Literary Theory", "A Survey of English Literature", and "Literature in Linguistics" are among the courses which he has usually taught. In the winter semester of 2014, he will start teaching a doctoral course: "Contemporary English Fiction," while in the semester next to that he will start teaching another doctoral course: " $17^{\text {th }}$-Century Poets." The main research interests of Ali Taghizadeh are fiction, literary theory, narrative studies, cultural studies, and literature in language. He has translated J. Hillis Miller's On Literature into Persian, and has published some research articles both in English and in his mother tongue. He is the English editor of Narrative Studies, which is a research journal published by the Department of Persian Language and Literature of Razi University. 